\title{
Effect of COVID-19 Prevention Measures on Air Quality in Thailand
}

\section{Aerosol and Air Quality Research}

Special Issue:

Special Issue on COVID-19 Aerosol Drivers, Impacts and Mitigation (XI)

\section{Jenjira Kaewrat ${ }^{1,2}$, Rungruang Janta ${ }^{1,2^{*}}$}

\author{
${ }^{1}$ School of Languages and General Education, Walailak University, Nakhon Si Thammarat, \\ 80160, Thailand \\ ${ }^{2}$ Center of Excellence in Sustainable Disaster Management, Walailak University, Nakhon Si \\ Thammarat, 80160, Thailand
}

\section{ABSTRACT}

The coronavirus disease 2019 (COVID-19) has been a global pandemic since early 2020. In Thailand, the number of cases increased exponentially from the middle of March 2020. In response, Thailand's government has imposed various pandemic prevention measures, such as a rigorous stay-at-home measure to reduce viral transmission between humans. Many human activities ceased, such as transportation, businesses, and services. This has been associated with reductions in air pollutant emissions. This study thus aimed to measure air quality in metropolitan, industrial, and suburban cities of in Thailand. Data on the hourly concentrations of six criteria pollutants were obtained from Thailand's Pollution Control Department from five stations during three measurement periods: pre-COVID, early COVID, and working-from-home (WFH) periods. The results indicated that vehicle-emitted pollutants had significantly decreased during WFH periods. Moreover, the air quality of all city types ostensibly improved (50\%-70\%) because of reduced transportation in Thailand's central and eastern provinces. However, results for Northern provinces were unclear because $\mathrm{PM}_{2.5}$ concentrations were still high during WFH period due to effects from open burning activity as well as meteorological condition.

Keywords: Coronavirus, Air quality index, Criteria pollutants, Potential source contribution function

\section{INTRODUCTION}

Coronavirus disease 2019 (COVID-19) broke out in Wuhan in China's Hubei Province in late December 2019. On January 30, 2020, the World Health Organization (WHO) declared the COVID-19 outbreak a so-called Public Health Emergency of International Concern (Sohrabi et al., 2020). COVID-19 spread rapidly worldwide, and the situation remains extremely serious at the time of writing. By May 19, 2020, over 4.7 million cases of COVID-19 had been reported worldwide, along with over 0.3 million deaths (WHO, 2020a). The older-adult population (aged $\geq 65$ years) is significantly more likely to have severe COVID-19 infections (Li et al., 2020). Thailand reported its first case of COVID-19 at the beginning of January 2020 in a Chinese tourist (WHO, 2020a). Many measures have been implemented by Thai authorities to reduce the risk of transmission, such as providing the public with information on COVID-19, giving recommendations for personal hygiene, and actively identifying and isolating patients. COVID-19 was in the early stage with fewer than 10 new cases per day until the middle of March 2020, and from then onward, the COVID-19 outbreak in Thailand began from clusters of pubs, restaurants, and boxing stadia. Cases increased exponentially from that period, with over 100 new cases reported daily (Thailand WHO, 2020b). Thailand's government imposed urgent measures to curb the spread of COVID-19. The country's health authorities implemented several recommended measures to curb the transmission of the virus from infected cases. These measures included the immediate isolation of the patient and contact tracing. Moreover, rigorous measures have been implemented, including a stay-at-home order as well as the postponement of national holidays, stoppage of public transportation, cancellation of all international and domestic flights, suspension of business 
operations, and control of movement between provinces. Economic and social activities have been greatly disrupted since the spread of COVID-19 in Thailand, and traffic density and industrial emissions have been greatly reduced because of the shutdowns. Such evidence has provided an opportunity to reduce air pollution related to human activity. Satellite data suggest that air pollution has decreased in many countries because of the COVID-19 outbreak (NASA, 2020), as has been the case in other countries around the globe, including China, Brazil, and Malaysia (Abdullah et al., 2020; Dantas et al., 2020; Xu et al., 2020). Studies investigating such reduced pollution have been mainly conducted in metropolitan cities. However, reduced air pollution has been evident in suburban cities, which are predominant in Southeast Asia (SEA).

Air pollution in SEA stems mainly from transportation, industry, open burning, and transboundary haze in rural and border areas. Particulate matter (PM), carbon monoxide (CO), nitrogen dioxide $\left(\mathrm{NO}_{2}\right)$, volatile organic compounds (VOCs), and polycyclic aromatic hydrocarbons (PAHs) are well-known traffic-related pollutants in cities. The composition of air pollutants in industrial areas is complicated. The composition of air pollutants including VOCs, $\mathrm{PM}, \mathrm{SO}_{2}, \mathrm{NO}_{2}$, and heavy metals-depend on industry type; by contrast, open burning is greatly associated with PM concentration in the area (Han and Naeher, 2006; Khamkaew et al., 2016; Saeaw and Thepanondh, 2015). Therefore, how COVID-19-prevention measures influence the quantity and quality of air pollution potentially depend on the type of area in question. Thus, this study aimed to compare variations in air pollutants and the Air Quality Index (AQI) in metropolitan, industrial, and suburban cities in Thailand during the COVID-19 outbreak. The results elucidate COVID-19's effects on air pollution in SEA.

\section{METHOD}

\subsection{Description of Study Sites}

Five provinces in Thailand were studied (Fig. 1), which were classified into three groups (metropolitan cities, industrial city and suburban cities) based on the size of their economy.

\subsubsection{Metropolitan cities}

Bangkok (BKK) is Thailand's capital city, located in the center of the country $\left(13^{\circ} 45^{\prime} \mathrm{N}\right.$, $100^{\circ} 29^{\prime} \mathrm{E}$ ). BKK has a tropical savanna climate with annual temperatures in the range of $10-40^{\circ} \mathrm{C}$ and rainfall of $1,600 \mathrm{~mm}$. BKK has a total area of $1,568.7 \mathrm{~km}^{2}$ and a population of 6 million, with a density of approximately 4,000 per $\mathrm{km}^{2}$. This area is the center of Thailand's economy and the

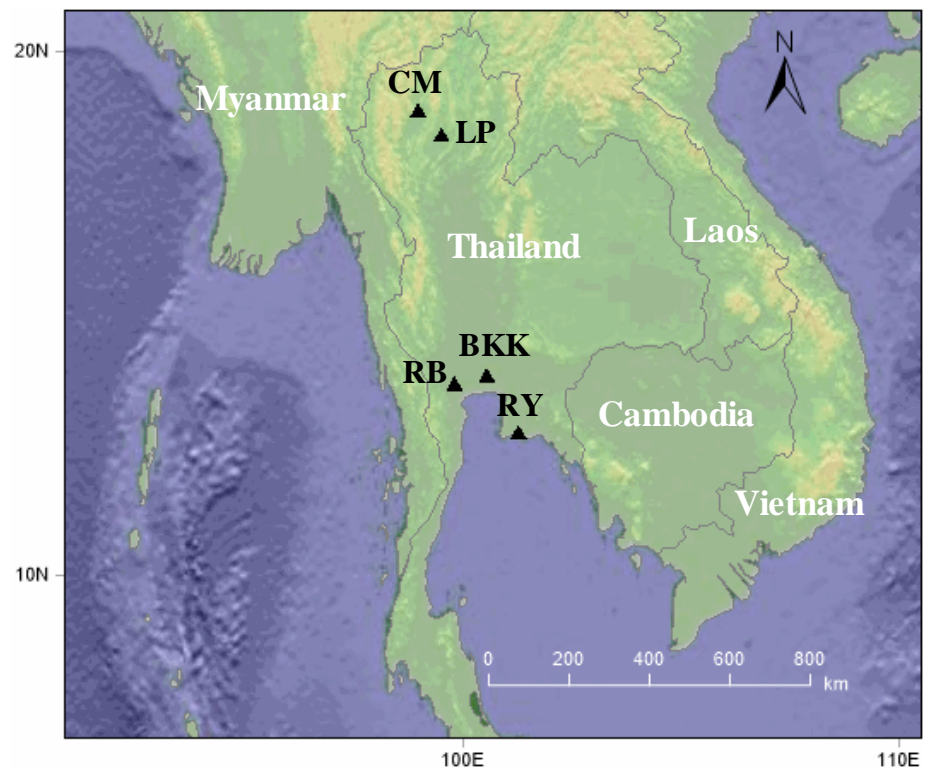

Fig. 1. The air pollution monitoring stations in each city: Chiang Mai (CM); Lampang (LP); Ratchaburi (RB); Bangkok (BKK) and Rayong (RY). 
hub of government and business. Ten million vehicles are registered in BKK (Department of Land Transport, 2020). A high population density coupled with an inadequate road and public transport network have led to heavy traffic congestion in BKK. Air quality data of BKK was obtained from air quality monitoring (AQM) stations installed in community areas 200 meters from main roads. Transportation is a major source of air pollution in this area.

Chiang Mai Province (CM) is the largest province in northern Thailand. The city of Chiang Mai $\left(18^{\circ} 47^{\prime} \mathrm{N}, 98^{\circ} 59^{\prime} \mathrm{E}\right)$ is located on a flat plain among mountains. $\mathrm{CM}$ has an area of $20,107 \mathrm{~km}^{2}$ and a population of 2 million with a density 100 people per km² (3,200 per km in Chiang Mai Municipality). The climate of $\mathrm{CM}$ is influenced by the South Asian monsoon system. Annual temperatures range between 4 and $42^{\circ} \mathrm{C}$, and the annual rainfall is $1,100 \mathrm{~mm}$. CM is a popular tourist destination, attracting over 10 million visitors every year. The Department of Land Transport reported the number of registered vehicles in CM at over 1.5 million in 2020. This province is rapidly expanding and becoming urbanized, with traffic congestion beginning to seriously affect air quality. The AQM station is installed at Chiang Mai City Hall, surrounded by community areas, agricultural areas and forest. Transportation and open burning are the main air pollution sources in $\mathrm{CM}$, with extra impact of open burning from neighboring countries during the dry season.

\subsubsection{Industrial city}

Rayong Province (RY) is located on the east coast of the Gulf of Thailand $\left(12^{\circ} 40^{\prime} \mathrm{N}, 101^{\circ} 16^{\prime} \mathrm{E}\right)$. RY has an area of $3,552 \mathrm{~km}^{2}$, with a population of 0.7 million people at a density of 200 per $\mathrm{km}^{2}$. $\mathrm{RY}$ has a tropical climate, with annual rainfall of 1,370 $\mathrm{mm}$. Annual temperatures range between 20 and $33^{\circ} \mathrm{C}$. Both industrial and tourism sectors are crucial for the population's income. An AQM station is installed at Rayong Provincial Agriculture Offices, surrounded by a community area and $15 \mathrm{~km}$ from the Map Ta Phut Industrial Estate to the west. RY has 0.8 million registered vehicles (Department of Land Transport, 2020). Air quality in this area is affected by both community and industrial emissions.

\subsubsection{Suburban cities}

Lampang Province (LP) is located in northern Thailand $\left(18^{\circ} 18^{\prime} \mathrm{N}, 99^{\circ} 30^{\prime} \mathrm{E}\right)$ with an area of $12,534 \mathrm{~km}^{2}$ and a population of 0.7 million at a density of 59 people per $\mathrm{km}^{2}\left(2,600\right.$ per $\mathrm{km}^{2}$ in the city). LP has a large coal-fired power plant (Mae Moh Power Plant), which can produce 2,400 MW of electricity per year ( $20 \%$ of Thailand's total capacity). The climate of LP is similar to that of CM. Annual temperatures range from 4 to $44^{\circ} \mathrm{C}$, with annual rainfall of $1,000 \mathrm{~mm}$. The number of registered vehicles in LP in 2020 was only 0.5 million. The AQM station is installed near the domestic airport in the city center, $30 \mathrm{~km}$ from the power plant to the northeast. This city also has an air quality problem during the dry season caused by open burning.

Ratchaburi Province (RB) is located in the west of Thailand $\left(13^{\circ} 32^{\prime} \mathrm{N}, 99^{\circ} 49^{\prime} \mathrm{E}\right)$ and is surrounded by mountains. RB has an area of $5,196 \mathrm{~km}^{2}$ and a population of 0.9 million at a density of 168 people per $\mathrm{km}^{2}$. Annual rainfall and average temperature are $1,100 \mathrm{~mm}$ and $27^{\circ} \mathrm{C}$, respectively. Local industry and livestock are essential to the economy of RB. Air quality data were obtained from the AQM station installed in the city of Ratchaburi. RB has only 0.5 million registered vehicles but traffic volume is very high along the roadway connecting BKK with the south of Thailand. Many activities including open burning, local industry (manual factories), transportation and construction are sources of pollution. In RB, $\mathrm{PM}_{2.5}$ exceeding the 24-h Thailand standard of $50 \mu \mathrm{g} \mathrm{m}^{-3}$ is usually observed during the dry season.

\subsection{Air Pollutant Concentrations}

The Thai government measures real-time hourly concentrations of six criteria pollutants, including particulate matter $\left(\mathrm{PM}_{2.5}\right.$ and $\left.\mathrm{PM} \mathrm{M}_{10}\right)$, sulfur dioxide $\left(\mathrm{SO}_{2}\right)$, nitrogen dioxide $\left(\mathrm{NO}_{2}\right)$, carbon monoxide ( $\mathrm{CO})$, and ozone $\left(\mathrm{O}_{3}\right)$ at various AQM stations. Air quality data was obtained on such measurements, for the period of November 2019 to May 2020, from the website of Thailand's Pollution Control Department (PCD; http://air4thai.pcd.go.th/webV2/history). The study period was divided into three periods according to the government's responses to COVID-19. These periods were the (1) pre-COVID period (November-December 2019, when Thailand had no instances of COVID-19); (2) early COVID period (January-February 2020, when the government 
provided information on COVID-19 and promoted personal hygiene), and (3) working-from-home (WFH) period (March-May 2020, when the government implemented strict measures to control the spread of the virus, such as suspending businesses and curbing inter-regional movement).

\subsection{Air Quality Index}

The PCD developed and is responsible for monitoring Thailand's AQI. The AQI combines the concentrations of six criteria pollutants $\left(\mathrm{PM}_{2.5}, \mathrm{PM}_{10}, \mathrm{CO}, \mathrm{SO}_{2}, \mathrm{NO}_{2}\right.$, and $\left.\mathrm{O}_{3}\right)$ into a single numerical value to indicate the level of air pollution. The concentration of six criteria pollutants, including the 24-h average concentrations of $\mathrm{PM}_{2.5}$ and $\mathrm{PM}_{10}$, daily average of the 8-h moving average concentrations of $\mathrm{CO}$ and $\mathrm{O}_{3}$, and average $1-\mathrm{h} \mathrm{NO} \mathrm{N}_{2}$ and $\mathrm{SO}_{2}$ concentrations, is applied to calculate the sub-AQI of each pollutant, as shown in Eq. (1). The highest sub-AQI contributor is defined as the AQI on that day (PCD, 2020). Some stations measured only the critical pollutant in their area; the AQIs of those areas were then calculated from the measured pollutants.

$I_{i}=\left[\frac{I_{\text {high }}-I_{\text {low }}}{C_{\text {high }}-C_{\text {low }}} \times\left(C_{i}-C_{\text {low }}\right)\right]+I_{\text {low }}$

$A Q I$ : maximum value among $I_{1}, I_{2}, \underline{I}_{3}, \ldots, I_{\mathrm{n}}$

$l_{i}$ : sub-AQI of criteria air pollutant $i$.

$C_{i}$ : concentration of air pollutant $i$.

$C_{\text {high }}$ : breakpoint concentration $\geq C_{i}$.

$C_{\text {low: }}$ breakpoint concentration $\leq C_{i}$.

Ihigh: I value corresponding to $C_{\text {high }}$.

Ilow: I value corresponding to $C_{\text {low. }}$

Based on Thailand's AQI, the AQI values can be classified into five classes: Grade I: 0-25 (excellent; light blue); Grade II: 26-50 (satisfactory; green); Grade III: 51-100 (moderate; yellow); Grade IV: 101-200 (unhealthy; orange), and Grade V: over 201 (very unhealthy; red) (PCD, 2020).

\subsection{Potential Source Contribution Function Analysis}

The potential source contribution function (PSCF) is applied to estimate the potential source of a dominant pollutant in a given set of study areas using backward trajectories (Punsompong and Chantara, 2018; Li et al., 2020). The PSCF is the ratio of the number of trajectory segment endpoints associated with an AQI value higher than a threshold value (falling in the $i j^{\text {th }}$ grid cell $m_{i j}$ ) with the total number of endpoints (falling within the $i j^{\text {th }}$ cell $n_{i j}$ ). The threshold is set at the $A Q I$ value of 100 because AQI values over 100 are at an unhealthy level. Cells with high PSCF values indicate a high potential source of the pollution at the receptor site. The PSCF value for the $i j^{\text {th }}$ cell can be derived using Eq. (2).

$P S C F_{i j}=\frac{m_{i j}}{n_{i j}}$

In this study, the TrajStat modeling system proposed by Wang et al. (2009) was used to compute backward trajectories and for the PSCF analysis. Moreover, meteorological data $\left(1^{\circ} \times\right.$ $1^{\circ}$ ) and the Global Data Assimilation System (GDAS) were used for calculations. The 3-day backward trajectories at 7:00 am and 7:00 pm local time at a height of $10 \mathrm{~m}$ above ground level were calculated for each study site. In total, 120 and 162 trajectories were computed in the early COVID-19 and WFH periods, respectively. The grid cell at $0.3^{\circ} \times 0.3^{\circ}$ resolution was generated for PSCF calculation. The weight function $w\left(n_{i j}\right)$ was applied to multiply the PSCF values to reduce uncertainties from the small value of $n_{i j}$ (Zhang et al., 2015).

\section{RESULTS AND DISCUSSION}

\subsection{Air Pollutant Concentrations}

The average concentrations of air pollutants in metropolitan and suburban cities during the 
pre-COVID-19, early COVID-19, and WFH periods are presented in Table 1 . The concentrations of air pollutants in the early COVID-19 period increased from those of the pre-COVID-19 period. This is attributable to 1) the COVID-19 spread being brought under control by Thailand's public health authority and 2) the government measures being mainly focused on personal hygiene and isolation of patients with COVID-19. Businesses were operating as usual. Moreover, this period marked the seasonal transition from winter to summer, with low humidity and wind speeds because of the decreased influence of monsoons. Additionally, temperature inversion was commonly noted in the early morning. These resulted in increased pollutant concentrations (Cichowicz et al., 2017). The concentration of particulate pollutants, including $\mathrm{PM}_{2.5}$ and $\mathrm{PM}_{10}$ in $\mathrm{RB}, \mathrm{RY}$, and BKK, were the lowest during the WFH period and had decreased by approximately $42 \%-55 \%$ from the early COVID-19 period (Fig. 2). An exception was observed in LP and CM, where the concentrations had been increasing since the end of the year because that period was marked by haze episodes in northern Thailand, of which the main source was the open burning of biomass. However, a decrease in concentrations was observed at the end of April because of heavy rain. In the case of gas pollutants, the concentrations of $\mathrm{CO}$ and $\mathrm{NO}_{2}$ exhibited significant reductions in the WFH period for all cities. As indicated in Fig. 2, COVID-19-induced decreases in human activity, especially in transportation, most significantly affected the levels of both pollutants. The findings indicated that $\mathrm{CO}$ and $\mathrm{NO}_{2}$ in Thailand are mainly generated from incomplete combustion and the internal combustion of vehicles (El-Fadel and Abi-Esber, 2009; Carslaw et al., 2019). In case of the secondary pollutant, $\mathrm{O}_{3}$ exhibited different pattern between

Table 1. Air pollutants concentration and AQI in suburban, industrial and metropolitan cities during COVID-19 period.

\begin{tabular}{|c|c|c|c|c|c|c|}
\hline \multirow{2}{*}{\multicolumn{2}{|c|}{ Air pollutants }} & \multicolumn{2}{|c|}{ Suburban cities } & \multicolumn{3}{|c|}{ Industrial and metropolitan cities } \\
\hline & & \multirow{2}{*}{$\begin{array}{l}\text { RB } \\
47.0 \pm 12.0^{\mathrm{a}}\end{array}$} & \multirow{2}{*}{$\begin{array}{l}\text { LP } \\
34.0 \pm 14.0^{\mathrm{a}}\end{array}$} & \multirow{2}{*}{$\begin{array}{l}\text { RY } \\
25.2 \pm 7.3^{\mathrm{a}}\end{array}$} & \multirow{2}{*}{$\begin{array}{l}\mathrm{CM} \\
31.3 \pm 9.3^{\mathrm{a}}\end{array}$} & \multirow{2}{*}{$\begin{array}{l}\text { BKK } \\
29.8 \pm 8.7^{\mathrm{a}}\end{array}$} \\
\hline $\mathrm{PM}_{2.5}$ & pre-COVID & & & & & \\
\hline$\left(\mu \mathrm{g} \mathrm{m}^{-3}\right)$ & early COVID & $54.5 \pm 18.8^{b}$ & $66.6 \pm 24.1^{\mathrm{b}}$ & $33.5 \pm 14.4^{b}$ & $49.3 \pm 17.4^{b}$ & $36.7 \pm 14.0^{b}$ \\
\hline & WFH & $24.5 \pm 8.6^{c}$ & $49.6 \pm 29.1^{c}$ & $18.5 \pm 2.7^{c}$ & $64.9 \pm 39.1^{c}$ & $18.3 \pm 6.1^{c}$ \\
\hline & $\%$ reducing* & $-55 \%$ & $-26 \%$ & $-45 \%$ & $32 \%$ & $-50 \%$ \\
\hline $\mathrm{PM}_{10}$ & pre-COVID & $88.9 \pm 17.1^{\mathrm{a}}$ & $55.9 \pm 14.8^{a}$ & $56.9 \pm 18.1^{a}$ & $46.4 \pm 8.7^{a}$ & $46.7 \pm 11.3^{a}$ \\
\hline \multirow[t]{3}{*}{$\left(\mu \mathrm{g} \mathrm{m}^{-3}\right)$} & early COVID & $100.0 \pm 24.2^{b}$ & $92.2 \pm 32.6^{b}$ & $58.8 \pm 21.6^{a}$ & $74.9 \pm 22.3^{b}$ & $54.5 \pm 17.0^{b}$ \\
\hline & WFH & $54.9 \pm 9.9^{c}$ & $78.0 \pm 32.0^{c}$ & $34.3 \pm 4.8^{b}$ & $91.0 \pm 47.2^{c}$ & $30.9 \pm 7.7^{c}$ \\
\hline & $\%$ reducing* & $-45 \%$ & $-15 \%$ & $-42 \%$ & $21 \%$ & $-43 \%$ \\
\hline $\mathrm{O}_{3}$ & pre-COVID & $40.3 \pm 8.4^{a}$ & $25.8 \pm 4.0^{\mathrm{a}}$ & $18.7 \pm 7.5^{\mathrm{a}}$ & $31.4 \pm 5.5^{a}$ & $32.6 \pm 8.7^{a}$ \\
\hline \multirow[t]{3}{*}{ (ppb) } & early COVID & $35.0 \pm 9.1^{b}$ & $36.3 \pm 6.6^{b}$ & $18.1 \pm 1.0^{\mathrm{a}}$ & $34.5 \pm 7.8^{a}$ & $36.1 \pm 8.8^{b}$ \\
\hline & WFH & $25.5 \pm 4.7^{c}$ & $47.1 \pm 11.0^{c}$ & $28.0 \pm 8.1^{b}$ & $41.7 \pm 8.3^{b}$ & $32.1 \pm 8.0^{\mathrm{a}}$ \\
\hline & \% reducing* & $-27 \%$ & $30 \%$ & $55 \%$ & $21 \%$ & $-11 \%$ \\
\hline $\mathrm{CO}$ & pre-COVID & $0.8 \pm 0.4^{a}$ & $0.6 \pm 0.1^{a}$ & $1.0 \pm 0.2^{\mathrm{a}}$ & N/A & $0.4 \pm 0.2^{\mathrm{a}}$ \\
\hline \multirow[t]{3}{*}{ (ppm) } & early COVID & $0.7 \pm 0.1^{b}$ & $0.9 \pm 0.2^{b}$ & $1.1 \pm 0.2^{b}$ & & $0.5 \pm 0.2^{b}$ \\
\hline & WFH & $0.4 \pm 0.1^{c}$ & $0.7 \pm 0.3^{a}$ & $0.6 \pm 0.3^{c}$ & & $0.3 \pm 0.1^{c}$ \\
\hline & \% reducing* & $-43 \%$ & $-22 \%$ & $-45 \%$ & & $-40 \%$ \\
\hline $\mathrm{NO}_{2}$ & pre-COVID & $10.9 \pm 2.4^{a}$ & $9.2 \pm 2.1^{\mathrm{a}}$ & $11.9 \pm 2.9^{a}$ & $10.7 \pm 3.0^{\mathrm{a}}$ & $25.5 \pm 6.2^{\mathrm{a}}$ \\
\hline \multirow[t]{3}{*}{ (ppb) } & early COVID & $11.3 \pm 4.0^{\mathrm{a}}$ & $12.6 \pm 4.0^{b}$ & $12.5 \pm 4.3^{\mathrm{a}}$ & $15.9 \pm 3.2^{b}$ & $20.5 \pm 7.5^{b}$ \\
\hline & WFH & $5.2 \pm 1.2^{\mathrm{b}}$ & $7.5 \pm 3.1^{c}$ & $5.7 \pm 2.1^{b}$ & $11.1 \pm 5.7^{\mathrm{a}}$ & $9.0 \pm 4.3^{c}$ \\
\hline & $\%$ reducing* & $-54 \%$ & $-40 \%$ & $-54 \%$ & $-30 \%$ & $-56 \%$ \\
\hline $\mathrm{SO}_{2}$ & pre-COVID & $1.8 \pm 0.7^{\mathrm{a}}$ & $1.5 \pm 0.4^{\mathrm{a}}$ & $1.1 \pm 0.2^{\mathrm{a}}$ & $1.1 \pm 0.2^{\mathrm{a}}$ & $\mathrm{N} / \mathrm{A}$ \\
\hline \multirow[t]{3}{*}{ (ppb) } & early COVID & $1.6 \pm 0.5^{\mathrm{ab}}$ & $1.8 \pm 0.5^{b}$ & $1.2 \pm 0.4^{a}$ & $1.0 \pm 0.2^{a}$ & \\
\hline & WFH & $1.3 \pm 0.4^{b}$ & $1.4 \pm 0.5^{a}$ & $1.5 \pm 0.5^{b}$ & $1.2 \pm 0.3^{\mathrm{a}}$ & \\
\hline & $\%$ reducing* & $-18 \%$ & $-22 \%$ & $25 \%$ & $20 \%$ & \\
\hline \multirow[t]{4}{*}{ AQI } & pre-COVID & $87 \pm 33^{a}$ & $49 \pm 37 a$ & $38 \pm 14^{a}$ & $43 \pm 22^{\mathrm{a}}$ & $42 \pm 17^{a}$ \\
\hline & early COVID & $108 \pm 49^{b}$ & $135 \pm 55^{b}$ & $50 \pm 36^{b}$ & $90 \pm 49^{b}$ & $59 \pm 35^{b}$ \\
\hline & WFH & $33 \pm 18^{c}$ & $98 \pm 59^{c}$ & $23 \pm 9^{c}$ & $127 \pm 67^{c}$ & $28 \pm 13^{c}$ \\
\hline & $\%$ reducing* & $-70 \%$ & $-28 \%$ & $-54 \%$ & $41 \%$ & $-50 \%$ \\
\hline
\end{tabular}

$\overline{a, b, c}$ present significant difference among of concentration from ANOVA test.

$\mathrm{N} / \mathrm{A}$; data is not available.

* is percentage of pollutant concentration reduction in WFH period from early COVID-19 period. 
Suburban cities

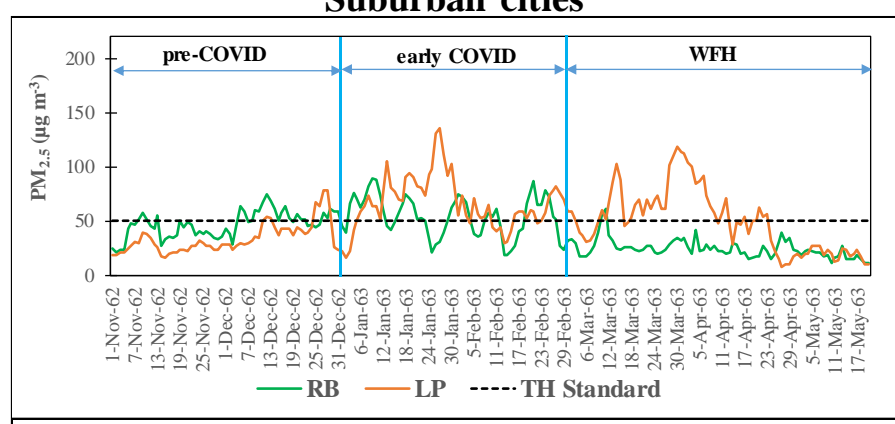

Industrial and Metropolitan cities
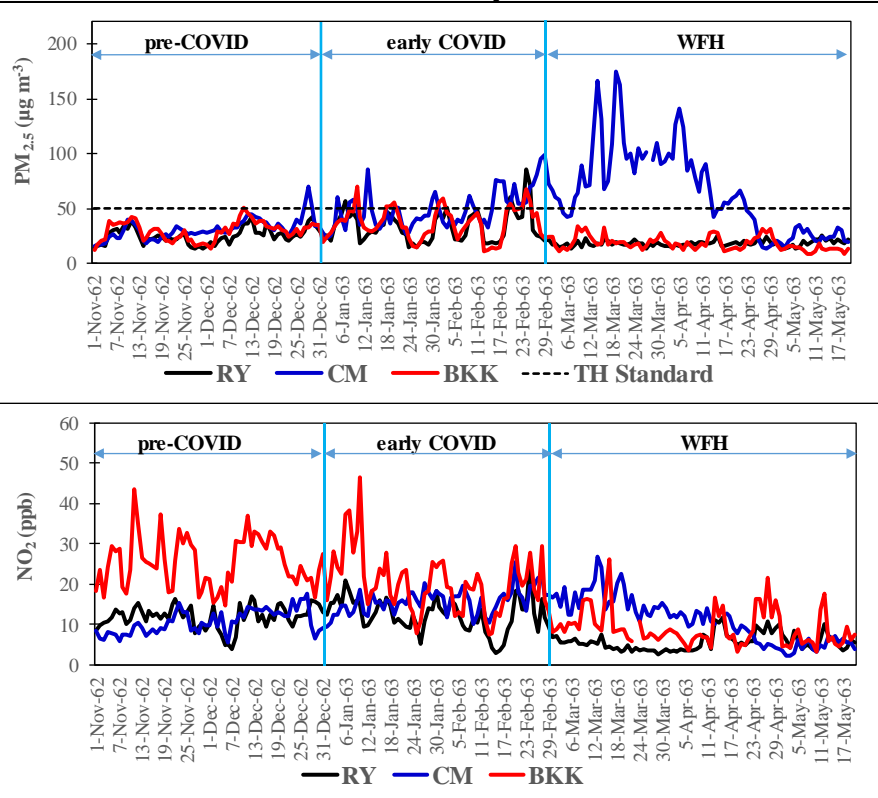

Fig. 2. Concentration of $\mathrm{PM}_{2.5}$ and $\mathrm{NO}_{2}$ in suburban, industrial and metropolitan cities.

cities. The ozone concentration decreased in RB and BKK, where road traffic is a source of $\mathrm{O}_{3}$ precursors, such as nitrogen oxides $\left(\mathrm{NO}_{x}\right)$ and hydrocarbons. The lower traffic volume and faster traffic flow on the roads during the WFH period potentially contributed to the reduced emission of $\mathrm{O}_{3}$ precursors (Munir et al., 2012). By contrast, LP, CM and RY presented increasing of $\mathrm{O}_{3}$ level because its precursors (the volatile organic compounds (VOCs) and $\mathrm{NO}_{\mathrm{x}}$ ) were emitted from both transportation and other sources such as open burning in LP and CM and industrial activities in RY (Rubio et al., 2015; Saeaw and Thepanondh, 2015). Moreover, the stronger solar intensity from March to April encourages greater photochemical activity and, by consequence, $\mathrm{O}_{3}$ production (Pochanart et al., 2001). Additionally, the faster ozone formation caused by high temperature in dry season in LP and CM could be the result of the greatest ozone level in LP and $\mathrm{CM}$ during WFM period (Coates, et al., 2016). $\mathrm{SO}_{2}$ concentration also increased in CM and RY, which was potentially influenced by biomass burning and industrial regions, respectively.

The diurnal variations of air pollutants in each city are presented in Fig. S1 of the Supplement. The blue, black, and red lines denote the hourly averages in the pre-COVID-19, early COVID-19, and WFH periods, respectively. Because the pre-COVID-19 period occurred during late winter in Thailand, whereas the other periods occurred in summer during which the same pollutant sources and metrological conditions were present. The hourly trends of pollutants in the WFH period were similar to those at the early COVID-19 period. Traffic-related pollutants such as $\mathrm{NO}_{2}$ and $\mathrm{CO}$ in the WFH period were significantly decreased from the corresponding levels at the early COVID-19 period especially at night because the government had imposed a curfew from 10:00 pm to 4:00 am as noted in Figs. S1(a) and S1(b). As indicated in Fig. S1(c) and S1(d) for the case of secondary pollutants $\left(\mathrm{O}_{3}\right)$ and $\mathrm{PM}$, a decreasing trend was observed in RB and BKK where the major sources are related to road-traffic characteristics but noted a negative result in cities such as $L P, R Y$, and $C M$ which have various pollutant sources. The results of pollutant concentrations indicated that the WFH measure was more likely to affect traffic-related pollutants than other pollutants.

\subsection{Air Quality Index during the COVID-19 Period}

Fig. 3 depicts the change in the AQI during the COVID-19 period. A significant improvement in air quality was discovered for most cites with the exception of CM, which was considerably affected by open burning causing smoke haze episode (Yabueng et al., 2020). Overall, the AQI during the WFH period exhibited a $28-70 \%$ decrease. RB exhibited the greatest decrease in the AQI (approximately 70\%), where air quality changed from an unhealthy to a satisfactory level 


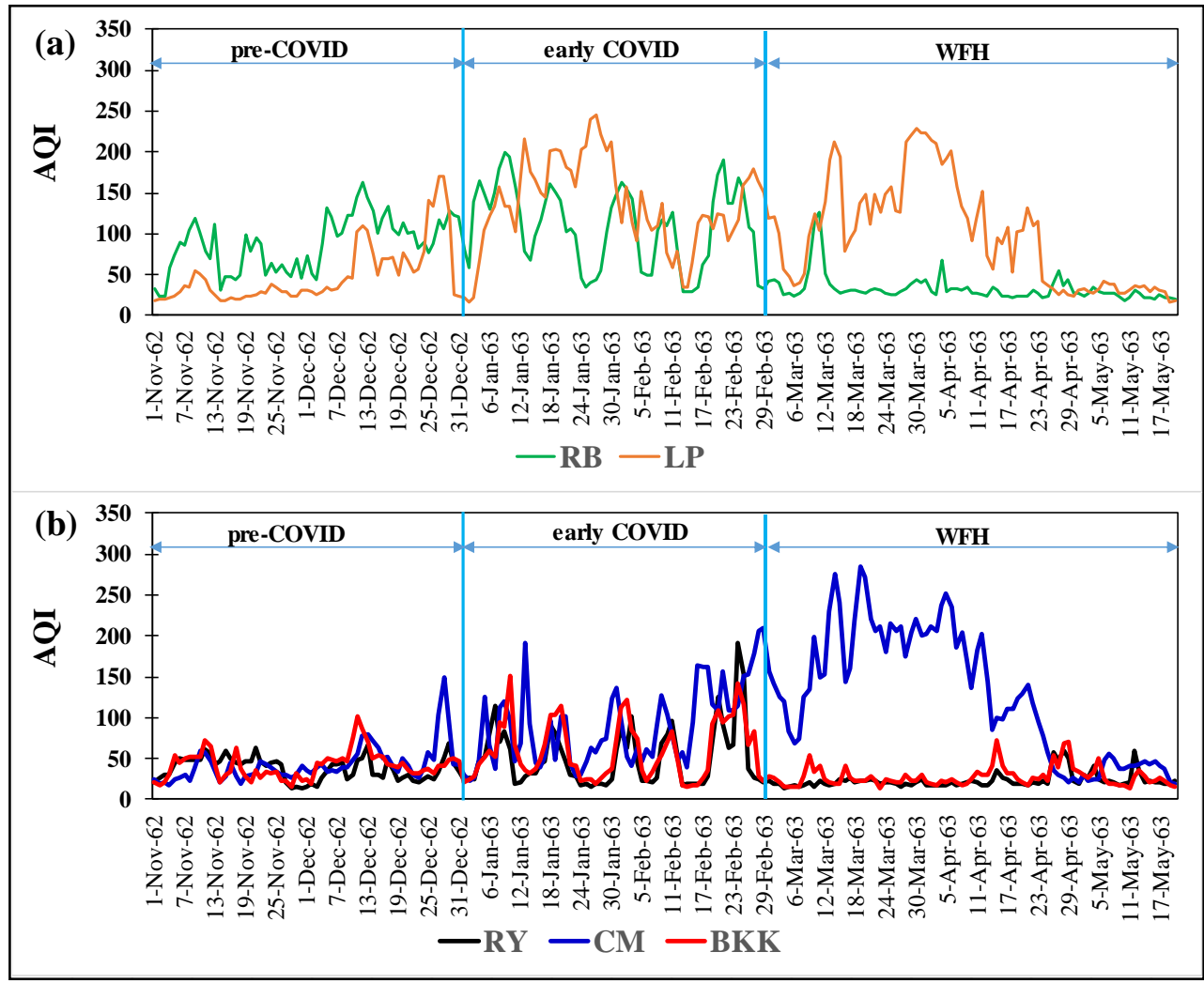

Fig. 3. Variation of AQI value during COVID-19 periods (a) suburban cities (b) industrial and metropolitan cities.

through a reduction in $\mathrm{PM}_{2.5}$. The $\mathrm{AQI}$ of $\mathrm{RB}$ before WFH period was the highest as a result of many human activities such as transportation, agricultural burning and manual factories. Moreover, Ratchaburi City is located in a valley and pollutants accumulate due to thermal inversion. Pollutant levels particular PM in RB were the highest but decreased when control of human activities was implemented. This result was similar to those for BKK and RY, where the air quality improved ( $50 \%$ reduction in AQI value) from moderate to satisfactory and from moderate to excellent for BKK and RY, respectively. In the case of the cities in northern Thailand (LP and $\mathrm{CM})$, the official ban on most human activity did not affect air quality because of uncontrolled activity e.g., open burning. However, this result suggests that $\mathrm{PM}_{2.5}$ is the dominant pollutant with the most significant influence on air quality in Thailand.

\subsection{Estimation of Potential Contributors to Air Pollution}

To estimate the potential source of unhealthy air quality from aerosol transactions, the PSCF was calculated and compared between the early COVID-19 and WFH periods. The PSCF threshold was set at the $A Q I$ value of 100 , an AQI over 100 indicates when a healthy individual experience health effects and when members of sensitive groups experience severe health effects. The PSCF results of the cities are presented in Fig. 4. The warmer grid color represents a greater potential source of the polluted area, one that contributes more to a high AQI value. As indicated in Fig. 4(a), both local area and the surrounding provinces presented the areas potentially contributing to the high AQI value in RB during the early COVID-19 period. The provinces to the south of RB are popular tourist destinations, such as Phetchaburi and Prachuap Khiri Khan. Moreover, the metropolitan cities in the center of Thailand, such as BKK, are located to the east of the province. The major sources of air pollution in RB were likely to be local human activities and pollutants being transported from neighboring metropolitan cities. Therefore, the reduction in human activity from the COVID-19 outbreak in metropolitan cities improved air quality in RB. Fig. 4(b) presents the potential sources of air pollution in BKK. This area is influenced by the northwest trade wind and the east coast current. However, the BKK air quality was mainly 

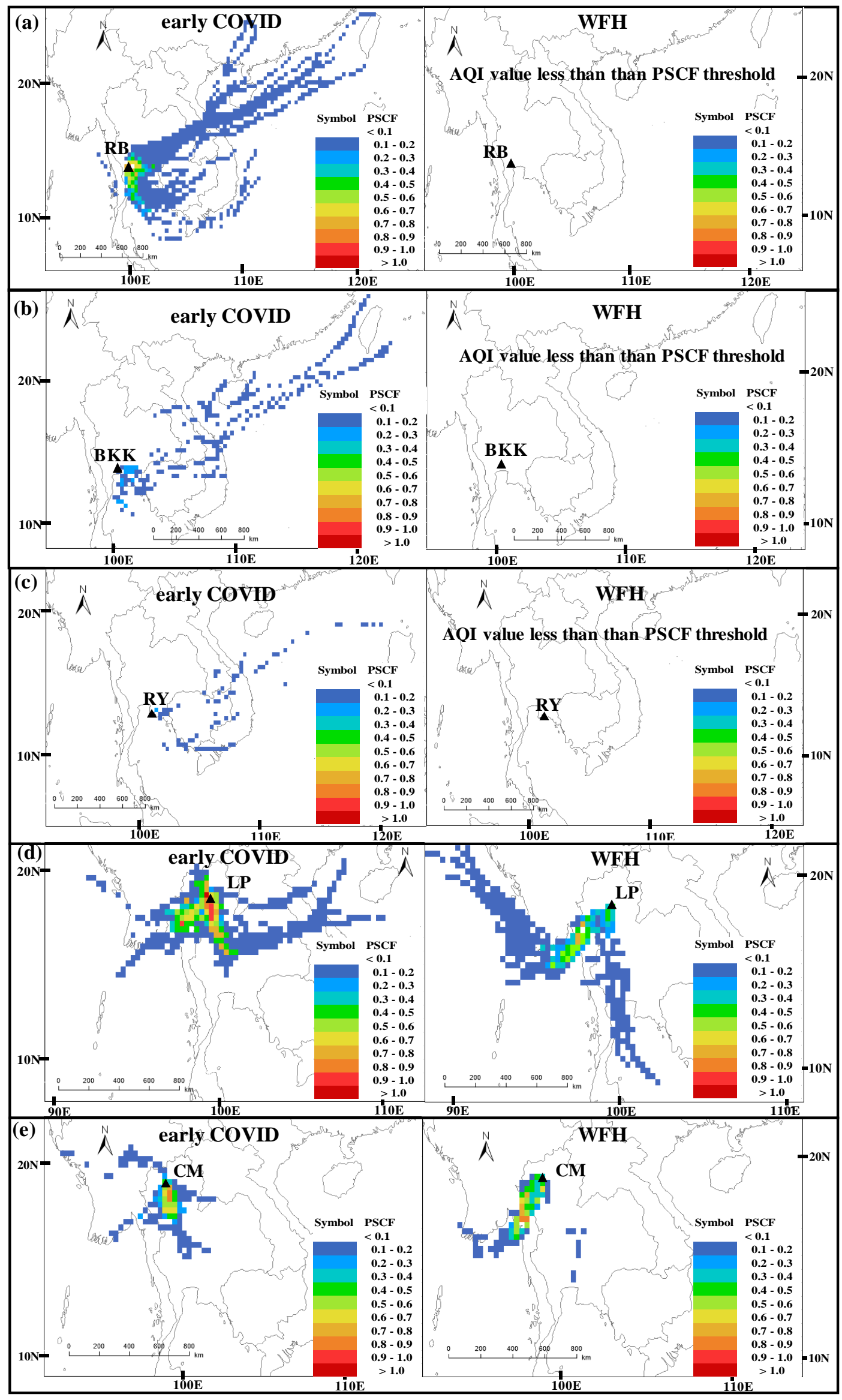

Fig. 4. PSCF of unhealthy AQI level during COVID-19 periods; (a) RB; (b) BKK; (c) RY; (d) LP; (e) CM. 
affected by local sources because of the city's prominent concentration of businesses. An improvement in air quality was also observed in BKK during the WFH period. The potential sources of air pollution in RY are presented in Fig. 4(c). Although air pollution in Rayong city was contributed from both neighboring countries and the local area, it seemed to be mainly influenced by local activities, as indicated by the small blue grid in Fig. 4(c). Additionally, the average pollution levels for the abovementioned cities improved to a satisfactory or excellent level (daily AQI value < 100). The results indicated that the dominant air pollutants $\left(\mathrm{PM}_{2.5}\right)$ contributing to these cities were influenced by human activities.

In the case of LP and CM, which are located in northern Thailand, their respective compositions of pollution sources were complex. As illustrated in Figs. 4(d) and 4(e), in the early COVID-19 period, the major sources were contributions from local and nearby cities. Because the study periods fell during a haze episode in the northern region of Thailand, both traffic-related pollutants and pollutants from forest fires, particularly PM were generated in those areas. After the WFH measure had been implemented, the source of pollution changed from the local area to the neighboring country and forested areas. However, the air parcels in the northern region of Thailand during this period normally move from cities in the southwest because of metrological conditions (Punsompong and Chantara, 2018). Therefore, whether WFH measures could reduce human-related pollutants in northern Thailand was not clearly indicated.

\section{CONCLUSION}

In response to the COVID-19 pandemic in Thailand, which began in January 2020, Thailand's government has implemented various measures to control the spread of infections. The measures began from the promotion of self-hygiene at the beginning of January 2020 to suspending business operations and ordering a WFH measure in the middle of March 2020. This study investigated the effect of restricting human activity on air quality in three classes of cities: metropolitan, industrial, and suburban. Significant decreases $(20 \%-50 \%)$ in $\mathrm{CO}$ and $\mathrm{NO}_{2}$, which are pollutants primarily from transportation, were observed for all classes of cities. Secondary pollutants were also reduced in the cities; some secondary pollutants include $\mathrm{PM}$ and $\mathrm{O}_{3}$, which are primarily from transportation. By contrast, pollutants from other sources, such as forest fires and industries, increased. Although the trends of average hourly concentrations during the early COVID-19 and WFH periods were similar, pollutant levels were generally lower during the WFH period, especially at night during the rigorously enforced stay-at-home measure. A significant improvement in air quality was observed in the recipient cities of traffic-related sources. Nevertheless, the relationship between air quality improvement and city class was not clearly indicated in this study; hence, the effects of emission sources and meteorological conditions should be further evaluated.

\section{SUPPLEMENTARY MATERIAL}

Supplementary data associated with this article can be found in the online version at https://doi.org/10.4209/aaqr.2020.06.0344

\section{REFERENCES}

Abdullah, S., Mansor, AA, Napi, NNLM, Mansor, W.N.W., Ahmed, A.N., Ismail, M., Ramly, Z.T.A. (2020). Air quality status during 2020 Malaysia Movement Control Order (MCO) due to 2019 novel coronavirus (2019-nCoV) pandemic. Sci. Total Environ. 729, 139022. https://doi.org/10.1 016/j.scitotenv.2020.139022

Carslaw, D.C., Farren, N.J., Vaughan, A.R., Drysdale, W.S., Young, S., Lee, J.D. (2019). The diminishing importance of nitrogen dioxide emissions from road vehicle exhaust. Atmos. Environ. 1, 100002. https://doi.org/10.1016/j.aeaoa.2018.100002

Cichowicz, R., Wielgosiński, G., Fetter, W. (2017). Dispersion of atmospheric air pollution in summer and winter season. Environ. Monit. Assess. 189, 605. https://doi.org/10.1007/s10661017-6319-2 
Coates, J., Mar, K.A., Ojha, N., Butler, T.M. (2016). The influence of temperature on ozone production under varying $\mathrm{NO}_{x}$ conditions $-\mathrm{A}$ modelling study. Atmos. Chem. Phys. 16, 1160111615. https://doi.org/10.5194/acp-16-11601-2016

Dantas, G., Siciliano, B., Franca, B.B., Silva, C.M., Arbilla, G. (2020). The impact of COVID-19 partial lockdown on the air quality of the city of Rio de Janeiro, Brazil. Sci Total Environ. 729, 139085. https://doi.org/10.1016/j.scitotenv.2020.139085

Department of Land Transport (2020). Number of Vehicle Registered in Thailand. https://web.dlt.go.th/statistics/index.php (accessed 5 September 2020).

El-Fadel, M., Abi-Esber, L. (2009). In-vehicle exposure to carbon monoxide emissions from vehicular exhaust: A critical review. Environ. Sci. Technol. 39, 585-621. https://doi.org/10.108 $0 / 10643380701798264$

Han, X., Naeher, L.P. (2006). A review of traffic-related air pollution exposure assessment studies in the developing world. Environ. Int. 32, 106-120. https://doi.org/10.1016/j.envint.2005.05.020

Khamkaew, C., Chantara, S., Janta, R., Pani, S.K., Prapamontol, T., Kawichai, S., Wiriya, W., Lin, N.H. (2016). Investigation of biomass burning chemical components over Northern Southeast Asia during 7-SEAS/BASELInE 2014 Campaign. Aerosol Air Qual. Res. 16, 2655-2670. https://doi.org/10.4209/aaqr.2016.03.0105

Li, L., Li, Q., Huang, L., Wang, Q., Zhu, A., Xu, J., Liu, Z., Li, H., Shi, L., Li, R., Azari, M., Wang, Y., Zhang, X., Liu, Z., Zhu., Y., Zhang, K., Xue, S., Ooi, M.C.G., Zhang, D., Chan, A. (2020). Air quality changes during the COVID-19 lockdown over the Yangtze River Delta Region: An insight into the impact of human activity pattern changes on air pollution variation. Sci. Total Environ. 732, 139282. https://doi.org/10.1016/j.scitotenv.2020.139282

Li, X., Xu, S., Yu, M., Wang, K., Tao, Y., Zhou, Y., Shi J., Zhou M., Wu. B., Yang, Z., Zhang, C., Yue, J., Zhang, Z., Renz, H, Liu, X., Xie, J., Xie, M., Zhao, J. (2020). Risk factors for severity and mortality in adult COVID-19 inpatients in Wuhan. Journal of Allergy and Clinical Immunology. Article impress. https://doi.org/10.1016/j.jaci.2020.04.006

Munir, S., Chen, H., Ropkins, K. (2012). Modelling the impact of road traffic on ground level ozone concentration using a quantile regression approach. Atmos. Environ. 60, 283-291. https://doi.org/10.1016/j.atmosenv.2012.06.043

NASA (2020). Airborne nitrogen dioxide plummets over China. https://earthobservatory.n asa.gov/images/146362/airborne-nitrogen-dioxide-plummets-over-china (accessed 5 May 2020).

Pochanart, P., Kreasuwun, J., Sukasem, P., Geeratithadaniyom, W., Tabucanon, M.S., Hirokawa, J., Kajii, Y., Akimoto, H. (2001). Tropical tropospheric ozone observed in Thailand. Atmos. Environ. 35, 2657-2668. https://doi.org/10.1016/S1352-2310(00)00441-6

Pollution control department (PCD) (2020). Thailand's air quality Information. http://air4thai.pcd.go.th/webV2/aqi_info.php (accessed 15 May 2020).

Punsompong, P., Chantara, S. (2018). Identification of potential sources of $\mathrm{PM}_{10}$ pollution from biomass burning in northern Thailand using statistical analysis of trajectories. Atmos. Pollut. Res. 9, 1038-1051. https://doi.org/10.1016/j.apr.2018.04.003

Rubio, M., Lissi, E., Gramsch, E., Garreaud, R., (2015). Effect of nearby forest fires on ground level ozone concentrations in Santiago, Chile. Atmosphere 6, 1926-1938. https://doi.org/10.3390/a tmos6121838

Saeaw, N., Thepanondh, S. (2015). Source apportionment analysis of airborne VOCs using positive matrix factorization in industrial and urban areas in Thailand. Atmos. Pollut. Res. 6, 644-650. https://doi.org/10.5094/APR.2015.073

Sohrabi, C., Alsafi, Z., O’Neill, N., Khan, M., Kerwan, A., Al-Jabir, A., losifidis, C., Agha, R. (2020). World Health Organization declares global emergency: A review of the 2019 novel coronavirus (COVID-19). Int. J. Surg. 76, 71-76. https://doi.org/10.1016/j.ijsu.2020.02.034

Wang, Y.Q., Zhang, X.Y., Draxler, R.R. (2009) TrajStat: GIS-based software that uses various trajectory statistical analysis methods to identify potential sources from long-term air pollution measurement data. Environ. Modell. Software 24, 938-939. https://doi.org/10.1016/j.envsof t.2009.01.004

World Health Organization (WHO) (2020a). Coronavirus disease (COVID-2019) situation reports. https://www.who.int/emergencies/diseases/novel-coronavirus-2019/situation-reports (accessed 15 May 2020). 
World Health Organization (WHO) (2020b). COVID-19 - WHO Thailand Situation Reports. https://www.who.int/thailand/emergencies/novel-coronavirus-2019/situation-reports (accessed 15 May 2020).

Xu, K., Cui, K., Young, LH., Hsieh, YK., Wang, YF., Zhang, J., Wan, S. (2020). Impact of the COVID19 event on air quality in central China. Aerosol Air Qual Res. 20, 915-929. https://doi.org/10. 4209/aaqr.2020.04.0150

Yabueng, N., Wiriya, W., Chantara, S. (2020). Influence of zero-burning policy and climate phenomena on ambient $\mathrm{PM}_{2.5}$ patterns and PAHs inhalation cancer risk during episodes of smoke haze in Northern Thailand. Atmos. Environ. 232, 117485. https://doi.org/10.1016/j.at mosenv.2020.117485

Zhang, Z.Y., Wong, M.S., Lee, K.H. (2015). Estimation of potential source regions of $\mathrm{PM}_{2.5}$ in Beijing using backward trajectories. Atmos. Pollut. Res. 6, 173-177. https://doi.org/10.5094/APR.20 15.020 